International Journal of Current Advanced Research

ISSN: O: 2319-6475, ISSN: P: 2319 - 6505, Impact Factor: SJIF: 5.995

Available Online at www.journalijcar.org

Volume 6; Issue 4; April 2017; Page No. 3462-3463

DOI: http://dx.doi.org/10.24327/ijcar.2017.3463.0294

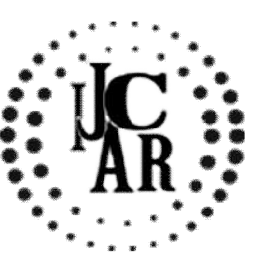

Research Article

\title{
STUDY OF PEAK EXPIRATORY FLOW RATE AMONG MASONRY WORKERS
}

\section{Saranya S}

Saveetha Dental College, Chennai, India

\begin{tabular}{l}
\hline A R T I C L E I N F O \\
\hline Article History: \\
Received $17^{\text {th }}$ January, 2017 \\
Received in revised form $10^{\text {th }}$ February, 2017 \\
Accepted $22^{\text {nd }}$ March, 2017 \\
Published online $28^{\text {th }}$ April, 2017 \\
\hline
\end{tabular}

Key words:

Masonry Workers, Peak Expiratory

\begin{abstract}
A B S T R A C T
Aim \& objective: To do a study of peak expiratory flow rate among masonry workers Background: the study was designed to compare the peak expiratory flow rate among masonry workers in Chennai. This study may also prevent the occupational hazards Reasons: To prevent the occupational hazards and to take preventive measures like proper ventilation as usage of mask in the work place
\end{abstract}

Copyright $₫ 2017$ Saranya S. This is an open access article distributed under the Creative Commons Attribution License, which permits unrestricted use, distribution, and reproduction in any medium, provided the original work is properly cited.

\section{INTRODUCTION}

Construction industry is one of the stable growing industries of the world and in India it is the largest economic activity after agriculture. Construction workers are at a greater risk of developing certain health disorders and sickness than workers in many other industriees. Mesothelioma is another type of cancer which is caused by inhalation of asbestos dust in work places such as public building ship yards etc. These disease are more prevalent among masonry workers. Silicosis is a disease which is caused by the inhalation of silica particle which is suspended in air. It is characterised by the shortness of breath, cough, syonosis (bluish skin).

PEFR was pioneered by Martin wright in 1950, later it wasdeveloped into mini wright flow meter. PEFR (Peak Expiratory Flow Rate) used to measure the maximum expiration of human which helps to find out the capacity of the lung. It is a small hand held device light weight, portable and cost efficient. The peak expiratory rate will be high when the person is exposed to any respiratory disease or asthma, peak expiratory flow reading is recorded to find out the health of the individual or the severity of asthma and to determine the treatment.

\section{MATERIALS AND METHODS}

Study period: The study period was on December 2017

Study design:

Place of study: The study was done with the masonry workers in Chennai.

*Corresponding author: Saranya $\mathbf{S}$

Saveetha Dental College, Chennai, India
The study was approved by the physiology department in saveetha dental college.

Inclusion criteria

- $\quad$ Age group $20-55$

- Both men and women were taken in this study.

- Exclusion criteria:

- People who had hypertension and diabetes where excluded

- People who was suffering with respiratory disease was excluded from the study

- Smokers and alcoholics

- Pregnant women.

- Any other medical anomalies

Technique to use wright expiratory flow meter

- The person should stand erect

- Place the meter between the teeth

- Blow as fast as they can inside the meter.

- Close the nose and blow inside the meter

\section{DISCUSSION}

The peak expiratory flow experiment is done among the masonry workers to find out there expiratory rate. Similar research says that once occupational asthma develops, the asthma will be induced by many non-specific triggers common to non-occupational asthma. The challenge is to identify changes in peak expiratory flow due to work among other non-occupational causes. Standard statistical tests have been found to be insensitive or non-specific, principally because of the variable period for deterioration to occur after 
exposure, and the sometimes prolonged time for recovery to occur, such that days away from work may initially have lower measurements than days at work ${ }^{(1)}$. According to the study done in about PEFR in construction site workers it is evident that the results of the present study showed a significant decrease in the mean values andvalue of $\mathrm{FVC}$, FEVin construction workers and this impairment was increased with duration of exposure to dust in construction site. (2) In a study involving people who were exposed to asbestos dust their peak flow was less in most of the men in the more exposed group, indicating an increased upstream resistance. This suggests that the changes responsible for the increased elastic recoil had a peribronchiolar rather than an alveolar location,. The changes in pulmonary mechanics were considered to be early because they occurred in men who had no radiographic evidence of disease or definitive changes in other measurements of lung function ${ }^{(3)}$ data was collected from $387(94.4 \%)$ workers. Most of them belonged to the young age group (26.8 years). The prevalence of past morbidity like tuberculosis $(1 \%)$, malaria $(13.7 \%)$ and jaundice $(10.6 \%)$, typhoid $(3.4 \%)$ were higher than the generalpopulation in both groups without any statistically significant differences between them. Prevalence of injury was higher among civil work group (17.2\% and 6.6\%) Current fever, respiratory infection.,

\section{CONCLUSION}

The statistically analysed significant $\mathrm{p}$ value is 0.035 .This study may used to know the hazards of exposure to asbestos dust silica dust organic solvents etc this study may also prevent the occupational hazardous disease by using the preventive measures and decreased exposure work by shift method, proper ventilation, using masks while working time and routine physical examination for every one year.

\section{References}

1. Basavaraju K, Thejaswini KO, Vivek P, Arifuddin MK, and Kavitha BS. Department of Physiology, Sri Siddhartha Medical College, Tumkur, Karnataka, India.
2. Tuladhar B. Health impacts of Kathmandu's air pollution. Clean Energy Nepal, Environment and Public Health Organization. http:// www. Clean airinitiative.org/por

tal/system/files/59152_tuladharpape r.doc. Published September 2003. Accessed July 10, 2012.

3. Krzyzanowski M, Cohen A. Update of WHO air quality guidelines. Air QualAtmos Health. 2008;1:713.doi:10.1007/s11869-008-0008-9.

4. Medabala T, B.N. R, Mohesh M.I. G, Kumar M. P. Effect of Cigarette and Cigar Smoking on Peak Expiratory Flow Rate. Journal of Clinical and Diagnostic Research: JCDR. 2013;7(9):1886-1889. doi:10.7860/JCDR/2013/6726.3342.

5. Elmes PC. Inorganic dusts. In Hunter's Diseases of Occupations ed. Raffle PAB, Adams PH, Baxter PJ and Lee WR. Edward Arnold Publications (London) 1994: 421-428.

6. B Perrin, F Lagier, J L'Archeveque, A Cartier, LP Boul et, J Cote, JL Malo European Respiratory Journal 1992 5: 40-48; DOI:

7. S. Smilee Johncy, K. T. Ajay, G. Dhanyakumar, N. Prabhu Raj, T. Vivian Samuel. J Physiol Biomed Sci. 2011; 24(1): 9-13

8. Gilles Jodoin, G. W. Gibbs, P. T. Macklem, J. C. McDonald, Margaret R. Becklake

9. OCT 1971 American Review of Respiratory Disease

10. Source: International Journal of Medicine \& Public Health. Oct-Dec2013, Vol. 3 Issue 4, p225-229. 5p.

11. Author(s): Jayakrishnan, Thayyil; Thomas, Bina; Rao, Bhaskar; George, Biju

\section{How to cite this article:}

Saranya S (2017) ' Study Of Peak Expiratory Flow Rate Among Masonry Workers', International Journal of Current Advanced Research, 06(04), pp. 3462-3463.

DOI: http://dx.doi.org/10.24327/ijcar.2017.3463.0294 